\title{
Nucleotide Sequence of the Pilin Gene of Bacteroides nodosus 340 (Serogroup D) and Implications for the Relatedness of Serogroups
}

\author{
By KENNETH G. FINNEY, ${ }^{1 *}$ THOMAS C. ELLEMAN ${ }^{1}$ AND \\ DAVID J. STEWART ${ }^{2}$ \\ Divisions of Biotechnology ${ }^{1}$ and Animal Health ${ }^{2}$, \\ Commonwealth Scientific and Industrial Research Organization, \\ Parkville 3052, Australia
}

(Received 2 October 1987)

\begin{abstract}
The gene encoding pilin of Bacteroides nodosus 340 has been isolated and the nucleotide sequence determined. The gene is present as a single copy within the $B$. nodosus genome and a protein of $M_{\mathrm{r}} 16683$ can be predicted from the proposed coding region. A comparison of the predicted amino acid sequence with pilin from other strains of $B$. nodosus indicated that the protein of strain 340 (serogroup D) has a high degree of similarity with pilin of strain 265 (serogroup $\mathrm{H}$ ). The degree of similarity between pilins from these strains and from other $B$. nodosus serogroups is no greater than that between $B$. nodosus pilins and the homologous proteins of several different bacterial species. These findings suggest that serogroups $D$ and $H$ may form a subset of $B$. nodosus serogroups.
\end{abstract}

\section{INTRODUCTION}

Bacteroides nodosus is the infectious agent of ovine footrot, a contagious disease which has a severe effect on the profitability of sheep production. Although immunity is not a consequence of natural infection, vaccination with killed whole cells of $B$. nodosus elicits a prophylactic response (Egerton \& Burrel, 1970; Egerton \& Roberts, 1971) and cell-surface appendages referred to as pili (Brinton, 1959), or fimbriae (Duguid et al., 1955), have been identified as the major host-protective immunogen (Every \& Skerman, 1982; Stewart, 1978a, b; Stewart et al., $1982,1983 a$ ).

The pili of $B$. nodosus are flexible filamentous structures 5-6 $\mathrm{nm}$ in diameter and up to $10 \mu \mathrm{m}$ in length (Every, 1979; Stewart, 1973; Walker et al., 1973). They are composed solely of the protein pilin, which has an $M_{\mathrm{r}}$ of 16500 to 19000 (Anderson et al., 1986; Stewart et al., 1986). Many bacterial species are piliated and pilins from $B$. nodosus, Moraxella bovis, $M$. nonliquefaciens, Neisseria gonorrhoeae, $N$. meningitidis and Pseudomonas aeruginosa display extensive $\mathrm{N}$-terminal amino acid sequence homology (Elleman et al., 1986 b; Marrs et al., 1985; McKern et al., 1983; Olafson et al., 1985). The similarity of these pilins, which have been designated $N$-methylphenylalanyl (N-mPhe) pilins (Elleman et al., 1986 b; Marrs et al., 1985), has been further demonstrated by the expression of $B$. nodosus pili in $P$. aeruginosa as morphologically correct structures (Elleman et al., 1986c; Mattick et al., 1987).

Despite the conservation of sequence at the $\mathrm{N}$-terminus, pilins from different strains of $B$. nodosus are highly variable beyond this region (McKern et al., 1986), giving rise to serological variation. On the basis of cross-reactivity in agglutination reactions involving the pilus, field isolates of the organism have been divided into a number of serogroups, with some groups further divided into subtypes (Claxton et al., 1983). Nine serogroups, designated A through I, are presently recognized (Claxton, 1986) and protection against footrot following vaccination is restricted to the serogroup from which the vaccine was prepared. 
An analysis of the differences between the serogroups of $B$. nodosus will require pilin sequence data for at least one representative of each serogroup. The amino acid sequences of pilin from strains 198,238 and 265 , representatives of serogroups $A, G$ and $H$ respectively, have been derived from the nucleotide sequences of the isolated pilin genes (Elleman \& Hoyne, 1984; Elleman et al., 1984, 1986b; Elleman \& von Ahlefeldt, 1987). In addition, the amino acid sequences of pilin from representatives of serogroups $B, C$ and $E$ have been determined (McKern et al., 1986; N. M. McKern, personal communication). In this report, we describe the isolation and characterization of the pilin gene from a representative of the $\mathrm{D}$ serogroup, strain 340 . The predicted amino acid sequence of strain 340 pilin is of special interest as this additional sequence, together with other data, indicates that there are two subsets of $B$. nodosus serogroups.

\section{METHODS}

Preparation of DNA and pili. B. nodosus 340 (CSIRO Animal Health Culture Collection) was cultured anaerobically at $37^{\circ} \mathrm{C}$ in modified Eugon broth (Claxton et al., 1983). After 2-3 d growth, cells were harvested and DNA and pili were prepared as previously described (Elleman et al., 1984; Stewart et al., 1983b).

Hybridization procedures. The hybridization probe used for the identification of DNA fragments bearing the pilin gene was derived from $B$. nodosus 198 and consisted of the upstream region and 160 nucleotides of the $5^{\prime}$ coding region of the pilin gene contained within a Sau3AI fragment of DNA cloned in M13mp8 (Elleman \& Hoyne, 1984). Following the isolation and sequence determination of the strain 340 gene, a HinPI-KpnI fragment of DNA from this strain was cloned in M13mpl8 and used as a probe in further confirmatory hybridization experiments. Probes were prepared using $\left[\alpha_{-32}{ }^{32}\right.$ P]dATP as described in detail elsewhere (Elleman et al., $1986 b$ ). Restriction endonuclease fragments bearing the pilin gene were identified with probes following fractionation in submerged agarose gels and transfer to nitrocellulose membrane (Smith \& Summers, 1980). Cells transformed by vectors harbouring such fragments of $B$. nodosus DNA were screened by probing colonies grown on nitrocellulose membranes (Maniatis et al., 1982). The highest stringency washes used were done at $65^{\circ} \mathrm{C}$ for $1 \mathrm{~h}$ with $0.2 \times \mathrm{SSC}$ $(1 \times \mathrm{SSC}$ is $0.15 \mathrm{M}-\mathrm{NaCl}$ plus $0.015 \mathrm{M}$-sodium citrate, $\mathrm{pH} \mathrm{7.0)}$ ) for transferred DNA and $1 \times$ SSC for colony probing, both containing $0 \cdot 1 \%(\mathrm{w} / \mathrm{v})$ SDS.

Immunoblotting procedure. Proteins expressed by transformed cells harbouring the pilin gene were extracted by heating cells collected from stationary-phase cultures at $100{ }^{\circ} \mathrm{C}$ for $2 \mathrm{~min}$ in a solution $(1 / 20$ of the culture volume) consisting of $2 \%(w / v)$ SDS and $1 \%(w / v)$ dithiothreitol. Samples $(5 \mu l)$ were then subjected to SDSpolyacrylamide gel $(15 \%, w / v)$ electrophoresis, transferred to nitrocellulose membrane and probed with sheep antiserum against purified pili from $B$. nodosus strain 340 (O’Donnell $e t$ al., 1983). Bound antibody was detected with ${ }^{125}$ I-labelled protein A.

Cloning of the pilin gene. B. nodosus $340 \mathrm{DNA}(8 \mu \mathrm{g})$ was digested with HindIII and the fragments were separated by submerged agarose gel electrophoresis. A fraction containing fragments of $2.5-3.5 \mathrm{kbp}$ was collected on NA45 membrane (Schleicher \& Schuell), extracted and ligated into HindIII-digested and phosphatase-treated pBR322 with a threefold molar excess of fragments over vector at a total DNA concentration of approximately $20 \mu \mathrm{g} \mathrm{ml}^{-1}$. Following the transformation of Escherichia coli RR1, cells harbouring the pilin gene were identified by hybridization, and the production of the protein encoded by this gene was confirmed by immunoblotting. Plasmid DNA was prepared from cells lysed with lysozyme/Triton $\mathrm{X}-100$ and purified by $\mathrm{CsCl} / \mathrm{ethidium}$ bromide equilibrium density-gradient centrifugation as previously described (Elleman et al., 1984).

Nucleotide sequence determination. DNA sequences were determined by the dideoxy chain-termination method (Sanger et al., 1977) using M13-cloned DNA (Messing, 1983) or alkaline-denatured and neutralized doublestranded DNA (Chen \& Seeburg, 1985) as templates (Fig. 1). Oligonucleotide primers were synthesized either manually (Elleman \& Hoyne, 1984) or automatically on an Applied Biosystems 381A DNA synthesizer and were purified by high-performance liquid chromatography.

\section{RESULTS}

\section{Identification of the pilin gene}

The probe derived from strain 198 DNA (see Methods) hybridized to a single band of $3.0 \mathrm{kbp}$ in HindIII-digested $B$. nodosus 340 DNA, so fragments of about this size were isolated for cloning of the pilin gene from the latter strain. E. coli transformants selected with the same probe contained plasmids bearing a single $3 \mathrm{kbp}$ insert at the HindIII site (Fig. 1), with the only variation between clones being the orientation of the insert. To verify that strain 340 pilin was encoded by the cloned DNA, protein extracts of these cells were subjected to immunoblotting. A single immunologically reactive protein of $M_{\mathrm{r}}$ approximately 17000 was detected in each case 


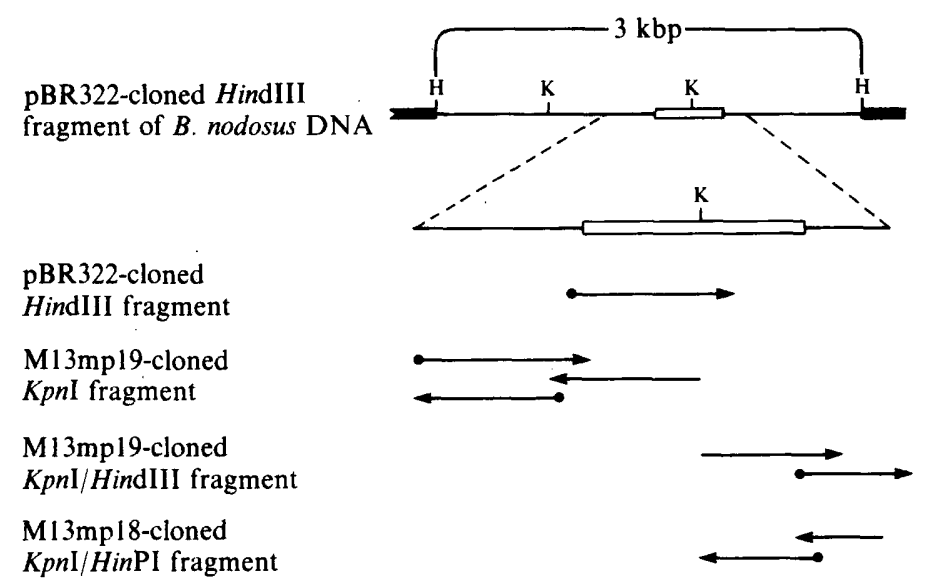

Fig. 1. Characterization of the pilin gene. A $3 \mathrm{kbp}$ fragment of $B$. nodosus 340 DNA cloned in pBR 322 is shown, with the pilin-coding sequence boxed. Transcription of the pilin gene occurs from left to right. Nucleotide sequences were derived directly from the plasmid or from subfragments cloned in M13 and are indicated by arrows which define the extent and direction of the determined sequence. The filled circles indicate the use of synthesized primers whose sequences were derived from the strain 340 sequence. HindIII and $K p n I$ sites are abbreviated as $H$ and $\mathrm{K}$ respectively.

(Fig. 2), a size comparable to that of pilin from strain 340 and similar to the protein expressed in $E$. coli cells harbouring the pilin gene from other strains of $B$. nodosus (Elleman et al., 1984, $1986 b$ ).

Sequence studies indicated a cloned subfragment of strain 340 DNA suitable as a specific hybridization probe for the pilin gene of this strain. The fragment extended from a $K p n I$ site within the pilin coding region to a HinPI site 173 nucleotides downstream from the termination codon (see below). Various restriction enzyme digests of genomic DNA were analysed with this probe to investigate the possibility that multiple pilin genes might be present within the $B$. nodosus genome (Fig. 3). Single bands were detected in HindIII, HindIII/KpnI and HaeII digests with sizes of $3.0,1.2$ and $0.9 \mathrm{kbp}$ respectively, in keeping with the restriction map generated from the pBR322-cloned material (Fig. 1) and the nucleotide sequence (Fig. 4), which revealed that the proposed coding region lay between $\mathrm{HaeII}$ sites $894 \mathrm{bp}$ apart. These results indicate that the pilin gene occurs as a single copy at a unique locus within the $B$. nodosus genome.

\section{Nucleotide sequence and predicted amino acid sequence}

The nucleotide sequence (Fig. 4) contains an open reading frame with features of the pilincoding sequence identified in other strains of $B$. nodosus (Elleman \& Hoyne, 1984; Elleman et $a l ., 1986 b$ ). These include a Shine-Dalgarno sequence (Shine \& Dalgarno, 1974), ${ }_{346}$ AGGAG, ahead of a possible initiation codon. Although two adjacent ATG triplets are present, translation would most probably be initiated at the second triplet since a minimum of five bases is generally found between the Shine-Dalgarno sequence and the initiation codon (Stormo et al., 1982). With translation initiated at the second ATG triplet, the reading frame would code for a protein of $M_{\mathrm{r}} 16683$, a value in agreement with that estimated for the immunologically reactive protein expressed by the transformed $E$. coli cells. Codon usage within the predicted amino acid sequence reflects trends previously noticed with other pilin structural genes (Elleman \& Hoyne, 1984; Elleman et al., 1986b). There is a preferential use of $U$ rather than $C$ in the third base position of quartet codons and a preferential use of $A$ rather than $G$ in the third base position of both quartet and duet codons.

\section{Comparison of sequences within the coding region}

The predicted amino acid sequence of the coding region of strain 340 was compared with the sequences of the same region from strains 198 and 265 (Fig. 5). Absolute identity occurs over the 


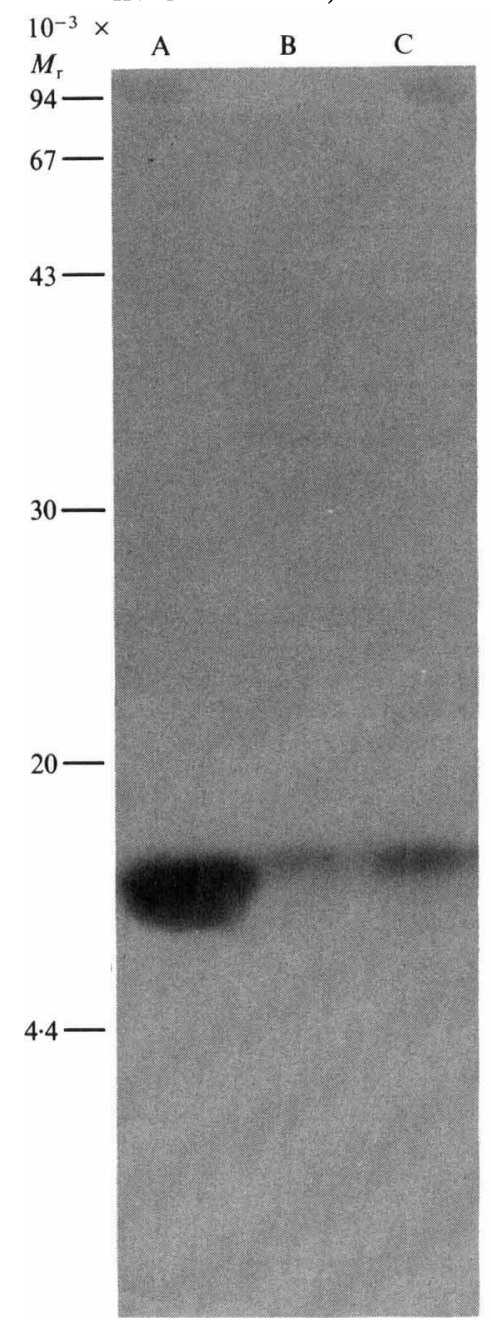

Fig. 2

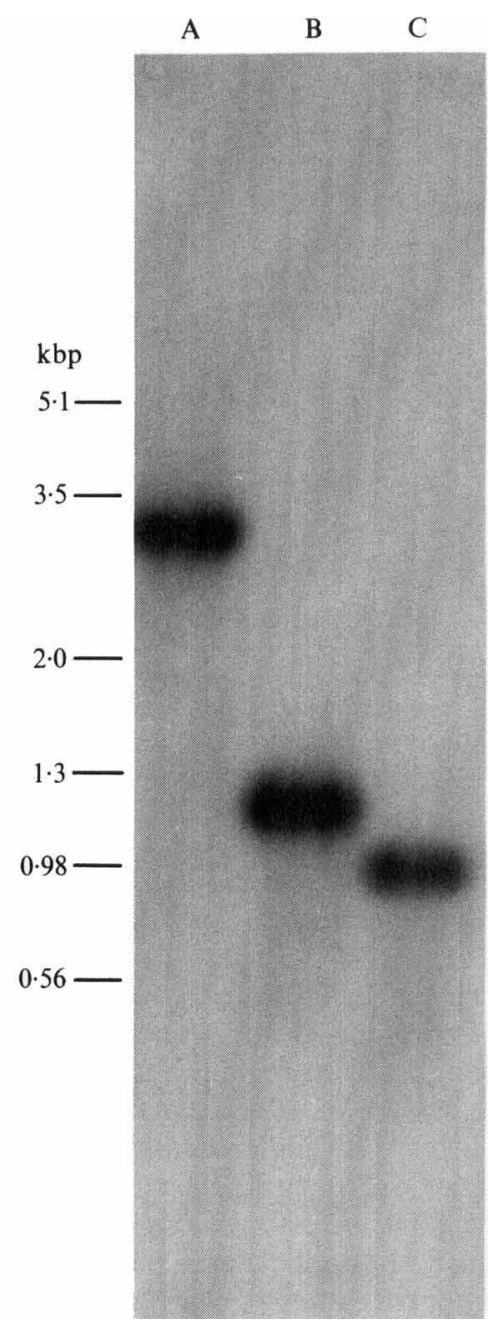

Fig. 3

Fig. 2. Immunoblot of $E$. coli cells harbouring recombinant plasmid. Lane A, purified B. nodosus 340 pili; lanes B and C, E. coli proteins from cells harbouring the pilin gene of $B$. nodosus 340 cloned as a $H$ indIII fragment in opposite orientations in pBR322. The positions of $M_{\mathrm{r}}$ standards are indicated to the left of the figure.

Fig. 3. Hybridization analysis. B. nodosus 340 DNA $(0.5 \mu \mathrm{g})$ was digested and fractionated in a submerged agarose gel $(1 \% \mathrm{w} / \mathrm{v})$. After transfer to nitrocellulose membrane, the DNA was probed with a M13mp18-cloned fragment of the pilin gene of B. nodosus 340 . Lanes A, B and C; HindIII, HindIII/KpnI, and HaeII digests respectively. The positions of size standards (EcoRI/HindIII-digested phage $\lambda$ DNA) are indicated to the left of the figure.

first 25 residues of each sequence, a segment which has been suggested as a topogenic signal common to all pilins of the N-mPhe type (Elleman et al., 1986c). Identity of sequence continues for an additional 32 residues between strains 340 and 265, and further extensive similarity throughout the remainder of these sequences results in an overall identity of $70 \%$. In contrast, there is little homology between the strain 198 sequence and that of the other two strains beyond residue 39 , and the total identity is not greater than $38 \%$ (Fig. 5). This value is within the range of identities found (33-43\%) between B. nodosus pilins and the N-mPhe-type pilins of other bacterial species (Table 1).

Diagonal matrices (Staden, 1982) were used to compare the nucleotide sequences of the pilin- 


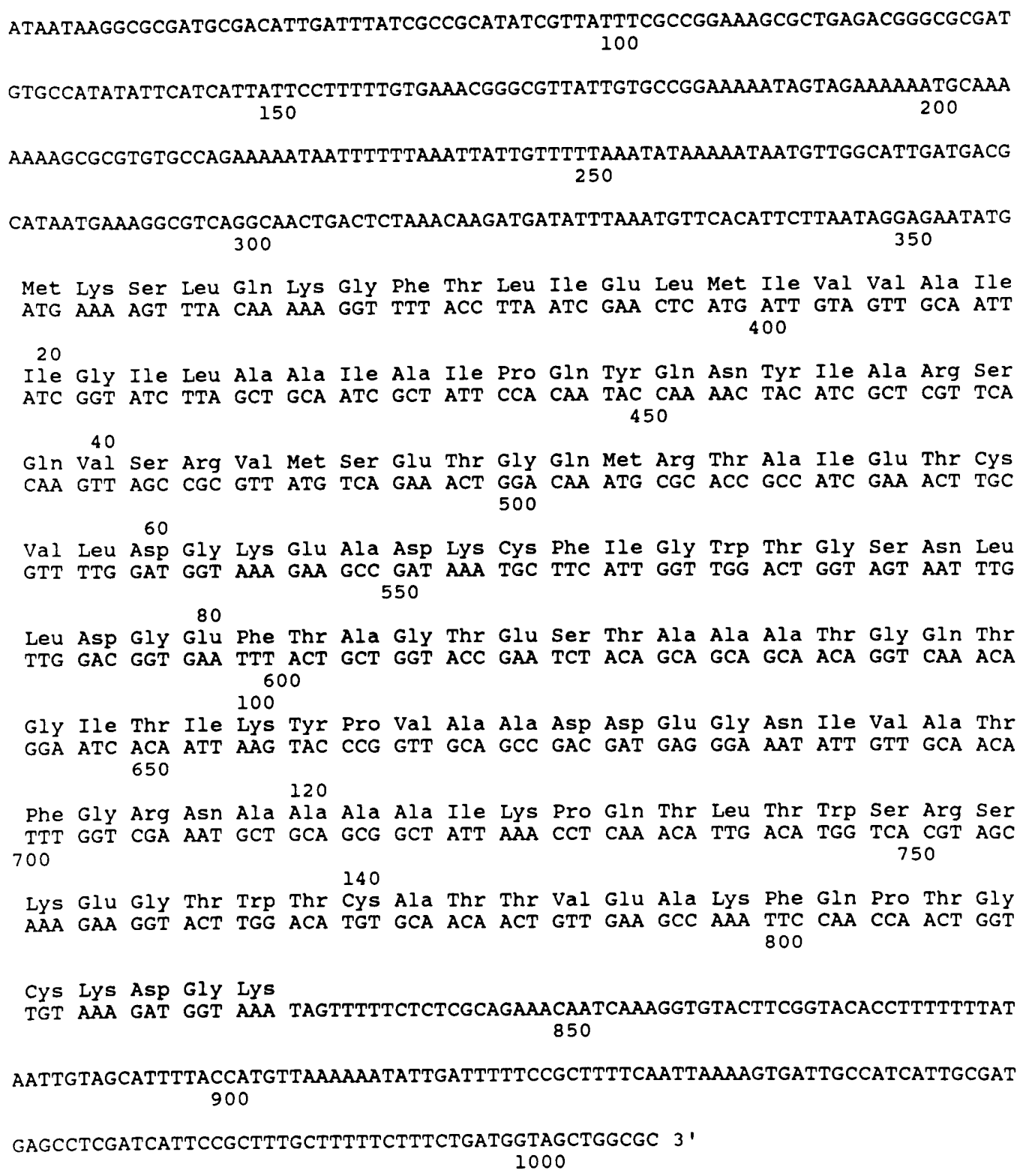

Fig. 4. Nucleotide sequence containing the pilin gene of $B$. nodosus 340 . The predicted amino acid sequence is presented above the nucleotide sequence.

coding regions of $B$. nodosus (data not shown) and revealed homologies corresponding to those seen in the amino acid sequences. Nucleotide sequence similarity was apparent throughout the comparison of strains 340 and 265 while similarity between these two strains and strain 198 was limited to the sequences encoding the $\mathrm{N}$-terminal region (residues 1 to 40 ) and the last 14 amino acids. Within the region encoding the invariant amino acids (residues 1 to 25), only three silent base changes have occurred between the strains, remarkably few considering the divergence of strains 340 and 265 relative to strain 198. 


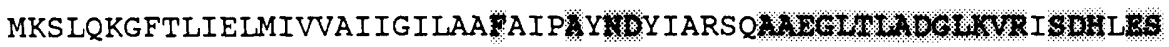

340 MKSLQKGFTLIELMIVVAIIGILAAIAIPQYQNYIARSQVSRVMSETGQMRTAIETCVLD

265 MKSLQKGFTLIELMIVVAI IGILAAIAI PQYQNY IARSQVSRVMSETGQMRTAIETCLLD

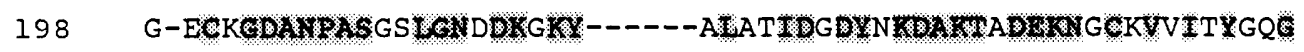

340 GKEADKCFIGWTGSNLLDEUWWATE-STAAATGQRGIIIXYPVAADOEG-UIVATFGRN

265 GKEGKDCFIGWTISNLLWMGGSTTWNATAABEQGGWNIWYWWEWWEX-KIEATFGQN

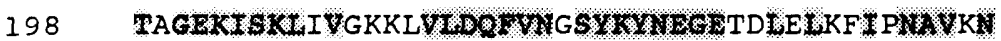 \\ 340 AAA-----AIKPOTLTWSRSKEGTW---KCATWVEAKFOPTGCKDEK \\ AAA-----TUEGKKLTWTRS EATW---SCWTDVDEKFRPTGCKX}

Fig. 5. Comparison of predicted amino acid sequences of pilin from B. nodosus 198, 340 and 265. Sequences were aligned with the aid of the ALIGN program (Dayhoff, 1976); residues in one sequence differing from the other two sequences at corresponding positions are shaded.

Table 1. Percentage identity between predicted amino acid sequences of bacterial pilins Additional sequences were obtained from the Genbank or NBRF databases. Sequences were aligned using the Needleman-Wunsch algorithm (Needleman \& Wunsch, 1970) with a unitary matrix and a gap penalty of 2 . Percentage identity is expressed as the number of matches relative to the total number of possible matches.

$\begin{array}{lcccc} & \begin{array}{c}\text { B. nodosus } \\ 198\end{array} & \begin{array}{c}\text { M. bovis } \\ \text { EPP63 } \beta\end{array} & \begin{array}{c}\text { N. gonorrhoeae } \\ \text { MS11 }\end{array} & \begin{array}{c}\text { P. aeruginosa } \\ \text { PAK }\end{array} \\ \text { B. nodosus 340 } & 36 & 43 & 36 & 41 \\ \text { B. nodosus 198 } & & 36 & 39 & 37 \\ \text { M. bovis EPP63 } \beta & & & 37 & 37 \\ \text { N. gonorrhoeae MS11 } & & & & 33\end{array}$

\section{Comparison of nucleotide sequences flanking the coding region}

In an alignment of nucleotide sequences 3 ' downstream of the proposed coding regions of the pilin gene from strains 198,265 and 340 , there is substantially greater similarity between strains 340 and 265 than between either of these two strains and strain 198 (Fig. 6). While strains 265 and 340 show $84 \%$ identity over the sequences compared, strain 198 displays less than half the number of identities. Within the downstream sequence of each strain, a region of hyphenated dyad symmetry followed by a string of thymidine residues is present which might constitute a transcription terminator for RNA polymerase (Platt, 1986). The potential stem and loop structures of the terminators from strains 340 and 265 are identical, with free energies $\left(\Delta G_{25}{ }^{\circ} \mathrm{C}\right)$ of $-64 \mathrm{~kJ} \mathrm{~mol}^{-1}$ compared with $-77 \mathrm{~kJ} \mathrm{~mol}^{-1}$ for the strain 198 sequence (Elleman et al., $1986 \mathrm{~b}$ ).

Sequences upstream of the pilin-coding regions of strains 198, 265 and 340 (Fig. 7) show more extensive similarities ( $>95 \%$ identity) than the downstream regions. However, contrary to the relatively greater similarity of strains 265 and 340 in both pilin-coding regions and downstream sequences, the most extensive similarity ( $99 \%$ identity) in the upstream region is between strains 198 and 265 . Very few base changes have occurred in the sequence immediately adjacent to the pilin-coding region and a potential promoter of the pilin gene has been identified in this area (Johnson et al., 1986). Further upstream, an open reading frame is present in the opposite 


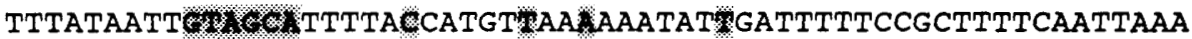

Fig. 6. Comparison of nucleotide sequences $3^{\prime}$ downstream of the coding region of the pilin gene from $B$. nodosus 198, 340 and 265 . Bases in one sequence differing from the other two sequences at corresponding positions are shaded. The ALIGN program (Dayhoff, 1976) was used to maximize matches between the sequences. Pilin termination codons are underlined and the arrows denote a region of hyphenated dyad symmetry in each sequence, the presumed transcription terminator.

50 GCGCACGGTAAAAAGCCGCGGATTTCCGTTTGTCCTTCTGCTAACGCTGCTAATAATAAG

100 A GCGCGATGCGACATTGATTTATCGCCGCATATCGTTATTTCGCCGGAAAGCGCTGAGACG C $\widetilde{2}-250 \quad \longrightarrow \quad$ A ATTATTGTTTTTAAATATAAAAATAATGTTGGCATTGATGACGCATAATGAAAGGCGTCA C 300 350 GGCAACTGACTCTAAACAAGATGATATTTAAATGTTCACATTCTTAATAGGAGAATATG

Fig. 7. Comparison of nucleotide sequences from the 5 upstream region of the pilin gene from $B$. nodosus 198, 340 and 265. The comparison begins at nucleotide 1 of Fig. 4 and ends at the nucleotide (356) immediately preceding the pilin-coding region. For the strain 198 and 265 sequences, only those bases that differ from the strain 340 sequence are shown. Regions of hyphenated dyad symmetry are indicated by arrows. 
orientation to that of the pilin coding sequence (Fig. 7) and this extends considerably beyond the presented data (T. A. A. Dopheide, personal communication). Within the open reading frame, an ATG triplet (reverse complement of ${ }_{141} \mathrm{CAT}$ ) is well situated with respect to a potential Shine-Dalgarno sequence, AAGGA (reverse complement of ${ }_{150}$ TCCTT) (Stormo et al., 1982). Many of the differences between strain 340 and strains 198 and 265 are concentrated in the extended ribosome-binding site (Stormo et al., 1982), including the first amino acid residues of this potential coding region. A sequence motif possessing hyphenated dyad symmetry is present mid-way between the initiation codons of the potential upstream coding region and the pilincoding region (Fig. 7).

\section{DISCUSSION}

Despite an absence of protein sequence data for pilin of $B$. nodosus 340 , the hybridization and immunoblotting results demonstrate that the DNA fragment isolated from this strain contains the pilin structural gene. In addition, the amino acid sequence predicted from the coding region of this gene has features characteristic of $B$. nodosus pilins and is especially similar to the protein from strain 265 . This similarity permits several predictions to be made with regard to the mature pilin of strain 340. Previous comparisons of nucleotide and amino acid sequences from $B$. nodosus 198 or 265 (Elleman et al., 1986b; McKern et al., 1983) have indicated that pilin is encoded as a preprotein from which the first seven residues are cleaved post-translationally in $B$. nodosus (Elleman \& Hoyne, 1984; Elleman et al., 1986a, b). Since the encoded sequences of the pilin genes of strains 198, 265 and 340 are identical in the $\mathrm{N}$-terminal region (Fig. 5), it is reasonable to assume that the strain 340 gene also encodes a preprotein which is subsequently cleaved in the same position as the preprotein of strains 198 and 265 . The relative mobilities of $B$. nodosus pilin and the immunologically reactive protein produced by $E$. coli cells harbouring the pilin gene (Fig. 2) support this assumption since the former has a slightly greater mobility than the $E$. coli protein from which the leader sequence is not removed (Elleman \& Hoyne, 1984).

The similarity throughout the amino acid sequences of pilin from strains 265 and 340 also allows a prediction to be made with regard to the disposition of disulphide linkages within the strain 340 protein. Cysteine residues are present at positions 57, 67, 140 and 153 of the predicted strain 340 sequence, and by analogy with pilin of strain 265 , in which cysteine residues are similarly located and of known linkage, disulphide linkages may exist between residues 57 and 67 and residues 140 and 153 of strain 340 pilin (Fig. 4). A disulphide loop near the C-terminus has been recognized as a homologous feature of pilins from several bacterial species (Elleman $e t$ $a l ., 1986 b$ ). Although this feature is present in strains 265 and 340, representatives of serogroups $\mathrm{H}$ and $\mathrm{D}$ respectively, it is absent from pilins of other $B$. nodosus serogroups, which contain a single, larger and more centrally located disulphide loop (McKern et al., 1983; N. M. McKern, personal communication).

Despite the extensive similarity between pilin of strains 340 (serogroup D) and 265 (serogroup $\mathrm{H}$ ), further processing by a central cleavage within the polypeptide chain, as found in pilins of serogroup $\mathrm{H}$, does not occur in pilins of serogroup D. Pilin of strain 265, although encoded as a single-chain protein of $M_{\mathrm{r}} 16637$ (Elleman et al., 1968 b), exists in pili largely as two subunits of $M_{\mathrm{r}}$ about 8000 (Anderson et al., 1986; Elleman et al., 1986 b; Stewart et al., 1986), a presumed proteolytic cleavage having occurred at an Ala-Ala bond between residues 79 and 80 (Fig. 5). Sequence differences in the corresponding region of strain 340 pilin might account for the absence of cleavage if the appropriate protease is present in this strain also. All other serogroups of $B$. nodosus are like serogroup $D$ in that pilin exists in pili as a single polypeptide chain (Anderson et al., 1986; Stewart et al., 1986).

Comparison of pilin amino acid sequences from representatives of different $B$. nodosus serogroups illustrates relationships beyond those recognized on the basis of serology (Claxton $e t$ al., 1983). As noted above, $70 \%$ identity exists between strains 265 (serogroup H) and 340 (serogroup D). However, no greater than $38 \%$ identity is shown between the protein from either of these strains and strain 198 pilin (serogroup A). In contrast, approximately $70 \%$ identity of sequence exists between pilins from representatives of serogroups A, B, C and E (Elleman et al., 
$1986 \mathrm{~b}$ ). An identity of about $70 \%$ is also found when the amino acid sequences of pilins from representatives of serogroups F (Dalrymple \& Mattick, 1987) and G (Elleman \& von Ahlefeldt, $1987)$ are compared with strain 198 pilin. There are thus two different types of $B$. nodosus pilins, those of serogroups $\mathrm{D}$ and $\mathrm{H}$ forming one subset and those of serogroups $\mathrm{A}, \mathrm{B}, \mathrm{C}, \mathrm{E}, \mathrm{F}$ and $\mathrm{G}$ another. This division of serogroups into subsets is further supported by comparison of the nucleotide sequences downstream of the coding region (Fig. 6): a considerably higher degree of similarity exists between strains 265 and 340 than between these sequences and that of strain 198. Conversely, the downstream sequence of strain 198 is virtually identical to strain 238 of serogroup $G$ in this region (Elleman \& von Ahlefeldt, 1987).

The comparison of pilins from $B$. nodosus with $\mathrm{N}$-mPhe-type pilins of other bacterial species shows that the similarity between different species is about the same as between the subsets of $B$. nodosus (Table 1). Clearly, generation of the subsets has occurred through more extensive nucleotide rearrangement than the changes responsible for the diversity of serogroups within a subset. A single pilin gene is present in the genome of $B$. nodosus, so the opportunity for homologous recombination does not exist as it does in species carrying multiple pilin gene sequences such as $N$. gonorrhoeae (Hagblom et al., 1985). However, recombination between nonhomologous sequences or foreign DNA may have given rise to sequence variation in the ancestral pilin genes of $B$. nodosus which resulted in formation of the subsets.

\section{REFERENCES}

Anderson, B. J., Kristo, C. L., Egerton, J. R. \& MatTICK, J. S. (1986). Variation in the structural subunit and basal protein antigens of Bacteroides nodosus fimbriae. Journal of Bacteriology 166, 453460.

BRINTON, C. C., JR (1959). Non-flagellar appendages of bacteria. Nature, London 183, 782-786.

Chen, E. Y. \& Seeburg, P. H. (1985). Supercoil sequencing: a fast and simple method for sequencing plasmid DNA. DNA 4, 165-170.

ClaXtON, P. D. (1986). Serogrouping of Bacteroides nodosus isolates. In Footrot in Ruminants, pp. 131134. Edited by D. J. Stewart, J. E. Peterson, N. M. McKern \& D. L. Emery. Sydney: CSIRO Australia and Australian Wool Corporation.

Claxton, P. D., Ribeiro, L. A. \& Egerton, J. R. (1983). Classification of Bacteroides nodosus by agglutination tests. Australian Veterinary Journal 60, 331-334.

DALRYMPle, B. \& MATtiCK, J. S. (1987). An analysis of the organization and evolution of type 4 fimbrial (mePhe) subunit proteins. Journal of Molecular Evolution 25, 261-269.

DAYHOFF, M. O. (1976). Atlas of Protein Sequence and Structure, vol. 5, supplement 2. Washington, DC: National Biomedical Research Foundation.

Duguid, J. P., SMith, I. W., Dempster, G. \& EDMUNDS, P. N. (1955). Non-flagellar filamentous appendages ("fimbriae") and haemagglutinating activity in Bacterium coli. Journal of Pathology and Bacteriology 70, 335-348.

Egerton, J. R. \& BurRell, D. H. (1970). Prophylactic and therapeutic vaccination against ovine foot-rot. Australian Veterinary Journal 46, 517-522.

EGERTON, J. R. \& ROBERTS, D. S. (1971). Vaccination against ovine foot-rot. Journal of Comparative Pathology 81, 179-185.

Elleman, T. C. \& Hoyne, P. A. (1984). Nucleotide sequence of the gene encoding pilin of Bacteroides nodosus, the causal organism of ovine footrot. Journal of Bacteriology 160, 1184-1187.
Elleman, T. C. \& von Ahlefeldt, D. A. (1987). Nucleotide sequence of the pilin gene from Bacteroides nodosus strain 238 (serogroup G). Nucleic Acids Research 15, 7189.

Elleman, T. C., Hoyne, P. A., Emery, D. L., STEWART, D. J. \& ClARK, B. L. (1984). Isolation of the gene encoding pilin of Bacteroides nodosus (strain 198), the causal organism of ovine footrot. FEBS Letters 173, 103-107.

Elleman, T. C., HoYne, P. A., Emery, D. L., Stewart, D. J. \& ClaRK, B. L. (1986a). Expression of the pilin gene from Bacteroides nodosus in Escherichia coli. Infection and Immunity 51, 187192.

Elleman, T. C., Hoyne, P. A., McKern, N. M. \& SteWART, D. J. (1986b). Nucleotide sequence of the gene encoding the two-subunit pilin of Bacteroides nodosus 265. Journal of Bacteriology 167, 243-250.

Elleman, T. C., Hoyne, P. A., Stewart, D. J., McKern, N. M. \& Peterson, J. E. (1986c). Expression of pili from Bacteroides nodosus in Pseudomonas aeruginosa. Journal of Bacteriology 168, 574-580.

EVERY, D. (1979). Purification of pili from Bacteroides nodosus and an examination of their chemical, physical and serological properties. Journal of General Microbiology 115, 309-316.

Every, D. \& Skerman, T. M. (1982). Protection of sheep against experimental footrot by vaccination with pili purified from Bacteroides nodosus. New Zealand Veterinary Journal 30, 156-158.

Hagblom, P., Segal, E., Billyard, E. \& So, M. (1985). Intragenic recombination leads to pilus antigenic variation in Neisseria gonorrhoeae. Nature, London 315, 156-158.

Johnson, K., PARKer, M. L. \& LORY, S. (1986). Nucleotide sequence and transcriptional initiation site of two Pseudomonas aeruginosa pilin genes. Journal of Biological Chemistry 261, 15703-15708.

Maniatis, T., Fritsch, E. F. \& Sambrook, J. (1982). Molecular Cloning : a Laboratory Manual, pp. 326- 
328. Cold Spring Harbor, NY: Cold Spring Harbor Laboratory.

MARRS, C. F., SCHOOLNIK, G., KOOMEY, J. M., HARDY, J., RothBaRD, J. \& Falkow, S. (1985). Cloning and sequencing of a Moraxella bovis pilin gene. Journal of. Bacteriology 163, 132-139.

Mattick, J. S., Bills, M. M., ANDerson, B. J., Dalrymple, B., Mott, M. R. \& Egerton, J. R. (1987). Morphogenetic expression of Bacteroides nodosus fimbriae in Pseudomonas aeruginosa. Journal of Bacteriology 169, 33-41.

MCKeRn, N. M., O'DONNell, I. J., INGlis, A. S., Stewart, D. J. \& Clark, B. L. (1983). Amino acid sequence of pilin from Bacteroides nodosus (strain 198), the causative organism of ovine footrot. FEBS Letters 164, 149-153.

MCKern, N. M., AREndshorst, S., Stewart, D. J., Clark, B. L. \& O'Donnell, I. J. (1986). Molecular basis of antigenic variation of pili from Bacteroides nodosus. In Footrot in Ruminants, pp. 229-232. Edited by D. J. Stewart, J. E. Peterson, N. M. McKern \& D. L. Emery. Sydney: CSIRO Australia and Australian Wool Corporation.

Messing, J. (1983). New M13 vectors for cloning. Methods in Enzymology 101, 20-78.

NeEdleman, S. B. \& WunsCh, C. D. (1970). A general method applicable to the search for similarities in the amino acid sequence of two proteins. Journal of Molecular Biology 48, 443-453.

O'Donnell, I. J., Stewart, D. J. \& Clark, B. L. (1983). Serological identification of pilus antigen and other protein antigens of Bacteroides nodosus using electro-blot radioimmunoassay after electrophoretic fractionation of the proteins on sodium dodecyl sulfate polyacrylamide gels. Australian Journal of Biological Sciences 36, 15-20.

Olafson, R. W., McCarthy, P. J., Bhatti, A. R., Dooley, J. S. G., Heckels, J. E. \& Trust, T. J. (1985). Structural and antigenic analysis of meningococcal piliation. Infection and Immunity 48, 336-342.

PlatT, T. (1986). Transcription termination and the regulation of gene expression. Annual Review of Biochemistry 55, 339-372.

SANGER, F., NickLen, S. \& Coulson, A. R. (1977). DNA sequencing with chain-terminating inhibitors. Proceedings of the National Academy of Sciences of the United States of America 74, 5463-5467.

ShINE, J. \& Dalgarno, L. (1974). The 3'-terminal sequence of Escherichia coli $16 \mathrm{~S}$ ribosomal RNA: complementarity to nonsense triplets and ribosome binding sites. Proceedings of the National Academy of
Sciences of the United States of America 71, 13421346.

Smith, G. E. \& Summers, M. D. (1980). The bidirectional transfer of DNA and RNA to nitrocellulose or diazobenzyloxymethyl-paper. Analytical Biochemistry 109, 123-129.

STADEN, R. (1982). An interactive graphics program for comparing and aligning nucleic acid and amino acid sequences. Nucleic Acids Research 10, 29512961.

StEWART, D. J. (1973). An electron microscopic study of Fusiformis nodosus. Research in Veterinary Science 14, 132-134.

StEWART, D. J. (1978a). The role of various antigenic fractions of Bacteroides nodosus in eliciting protection against foot-rot in vaccinated sheep. Research in Veterinary Science 24, 14-19.

StEWART, D. J. $(1978 b)$. Studies on the antigenic structure of Bacteroides nodosus. Research in Veterinary Science 24, 293-299.

Stewart, D. J., Clark, B. L., Peterson, J. E., GRIFFITHS, D. A. \& SMITH, E. F. (1982). Importance of pilus-associated antigens in Bacteroides nodosus vaccines. Research in Veterinary Science 32, 140147.

Stewart, D. J., Clark, B. L., Emery, D. L., Peterson, J. E. \& Fahey, K. J. (1983a). A Bacteroides nodosus immunogen, distinct from the pilus, which induces cross-protective immunity in sheep vaccinated against footrot. Australian Veterinary Journal 60, 83-85.

Stewart, D. J., Clark, B. L., Peterson, J. E., GRIFFITHS, D. A., SMITH, E. F. \& O'DONNELL, I. J. $(1983 \mathrm{~b})$. Effect of pilus dose and type of Freund's adjuvant on the antibody and protective responses of vaccinated sheep to Bacteroides nodosus. Research in Veterinary Science 35, 130-137.

Stewart, D. J., Peterson, J. E., Vaughan, J. A., Clark, B. L., Emery, D. L., Caldwell, J. B. \& KORTT, A. A. (1986). The pathogenicity and cultural characteristics of virulent, intermediate and benign strains of Bacteroides nodosus causing ovine foot-rot. Australian Veterinary Journal 63, 317-326.

Stormo, G. D., SCHNeider, T. D. \& Gold, L. M. (1982). Characterization of translational initiation sites in E. coli. Nucleic Acids Research 10, 2971-2996.

WALKer, P. D., ShORT, J., THOMSON, R. O. \& ROBERTS, D. S. (1973). The fine structure of Fusiformis nodosus with special references to the location of antigens asociated with immunogenicity. Journal of General Microbiology 77, 351-361. 